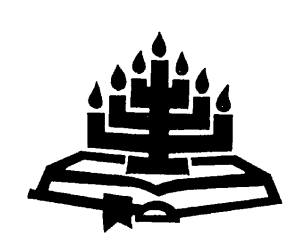

\title{
Feminist interpretation in the context of reformational theology: a consideration
}

\author{
C. Nunes \& H.J.M. van Deventer \\ Subject Group Theology \\ Vaal Triangle Campus \\ North-West University \\ VANDERBIJLPARK \\ E-mail: tyronnenunes@yahoo.com
}

Hans.VanDeventer@nwu.ac.za

\section{Abstract \\ Feminist interpretation in the context of reformational theology: a consideration}

This article explores the contribution that Biblical interpretation from a feminist perspective may make in the context of reformational theology. After an overview of the diverse nature of feminist Biblical interpretation that in itself stems from specific developments in hermeneutics, this article explores the contributions made by two prominent scholars in this field, namely Schüssler-Fiorenza and Trible. These contributions are then brought to bear on the South African situation and the debate on the role of women in the church. A suggestion is made as to the contribution that the work of Schüssler-Fiorenza and Trible can make in this context.

\section{Opsomming}

Feministiese interpretasie in die konteks van reformatoriese teologie: 'n oorweging

Hierdie artikel ondersoek die bydrae wat Bybelinterpretasie vanuit 'n feministiese perspektief kan maak binne die konteks van reformatoriese teologie. $\mathrm{Na}$ 'n oorsig rakende die diverse aard van feministiese Bybelinterpretasie, wat op sigself voortspruit uit ontwikkelings binne die hermeneutiek, ontgin hierdie artikel die bydraes van twee prominente navorsers in hierdie veld, naamlik Schüssler-Fiorenza en Trible. Hierdie bydraes word dan in verband gebring met die Suid-Afrikaanse situasie en die debat oor die rol van vroue in die kerk. 'n Voorstel word gemaak rakende 'n bydrae wat die werk van SchüsslerFiorenza en Trible in hierdie konteks kan lewer. 


\section{Introduction}

Over the years many significant developments took place in the field of general hermeneutics as well as Biblical hermeneutics. A look at these developments reveals the three major approaches to be historical, literary, and reader orientated or "interested" in nature. A feminist interpretation of the Bible is one of the interested approaches. Along with the development of feminism in general, this approach began in theological circles due to women's growing desire to be liberated from the limitations that the ideology of patriarchy placed on them, not only in society at large, but also in the church. Below the development of feminist hermeneutics in general is traced. The subsequent discussion will focus on the contributions made by two prominent theologians, namely Schüssler-Fiorenza and Trible. Schüssler-Fiorenza follows an historical approach to the understanding of this Biblical text to attain a feminist objective, while Trible makes use of a literary approach for a similar reason. The article then traces the development in three Afrikaans reformed churches related to the role of women in the church. In the last instance the value of feminist approaches such as those developed by Schüssler-Fiorenza and Trible in the context of reformational theology is considered.

\section{Feminist interpretation - a definition}

There are many differences among feminist Biblical scholars. Newport (1996:139) explains that some seek to explore Biblical characters, books and themes that are relevant to the modern woman's situation. Others read the complete text from a female perspective to see what differences there are between the way a woman understands the text and the way that a man understands it. A third group reads the Bible as women in order to speak-up against patriarchy. They want to expose the Bible as a possible tool of oppression against woman. In order to practise feminist Bible interpretation one reads and understands the Bible from the standpoint of a feminist theory of justice and a feminist movement for change (SchüsslerFiorenza, 2001:1).

Sawyer (1990:231) in essence sums up what all forms of feminist interpretation share with the following statement: "Feminist interpretation of the Bible offers an alternative assessment of the Biblical evidence as seen through the eyes and experience of women readers and theologians". According to Trible (1984:3) feminist hermeneutics is a prophetic movement, examining the status quo, pro- 
nouncing judgement and calling for repentance by engaging with Scripture in various ways.

It has been noted by Thiselton (1992:410) among others that feminist theology is related in some of its themes and concerns to liberation theology. Feminist writers, however, do not write as outsiders in defence of "the oppressed", but as insiders who are concerned with oppression in terms of gender. It is only with the development of third wave feminism towards the end of the twentieth century that specific class concerns also entered the fray. When it comes to offering a critique of patriarchal ideologies, feminist theology has to face the challenging task of working between the world of the Bible and the world in which we live (Gillingham, 1998:141).

In all the major areas of Christian theology today, feminists are proposing an alternative to the existing ways of interpretation in order to remove the harmful effects of patriarchy and accommodate the insights of women. By doing so, feminist theologians want the church and society at large to benefit explicitly from the contributions of half the race that experiences God in a female body (Carmody, 1995:66). Schüssler-Fiorenza (1985:55) explains that in traditional hermeneutics man was the paradigmatic subject of scientific knowledge and interpretation while women were defined as the other or the object of male interpretation. Feminist interpreters insist, however, on the re-conceptualisation of language as well as intellectual frameworks so that women, as well as men, are subjects of interpretation.

\section{Developments in hermeneutics and their meaning for women}

According to Phillips (1999:391) traditional Christian exegesis shows that women are subordinated to men in the order of creation and that a woman's purpose is fulfilled in her relationship to her husband. Bible passages like the second creation story in Genesis 2:4b3:24, the author's (Paul?) affirmation of men's headship in 1 Timothy 2:11-14, women's speaking in church being prohibited in 1 Corinthians 14:35-35 and women being taught to obey their husbands (Eph. 5:22-24; Col. 3:18-19; 1 Pet. 3:1-6) were all interpreted in such a way that people believe women's authority must be surrendered to their husbands and so to men in general (Phillips, 1999:391). This resulted in women not being allowed to interpret, teach and preach from the Bible. It can therefore be said that there is a direct correlation between Biblical hermeneutics and the role of women in 
the church. Women realised that altering the dominant perspective from which the Bible is read, can bring about new interpretation possibilities. This resulted in what is known as feminist Biblical interpretation.

It was already stated that variety exists in feminist interpretation. The three major groups within this field, namely revolutionary feminism, reformist feminism and reconstructionist feminism, are briefly considered here. There are, of course, also other ways to group together the main ideas in the field. Osiek (1997:960), for example, elaborates on the proposals by Ruether (1983) and Sakenfeld (1981, as quoted in Osiek, 1997) and describes the reaction of women in Christian communities to oppressing patriarchal structures under five headings. Although a more simplified proposal is used below in this general description, reference will be made to the demarcation suggested by Osiek as well.

\subsection{Revolutionary feminist theology}

This group can in fact be described as post-Christian. Most of these women have been part of Christianity at some stage, but their feminist consciousness led them to the conclusion that Christianity is irredeemably patriarchal and often in opposition to women (cf. Daly, 1983). The main problem that these women have with the Bible is the centrality given to the revelation of a male God by Christian churches. Furthermore, they are of the opinion that Christians continue to subordinate women in their churches and marital relationships. They conclude Christianity is oppressive to women and should be abandoned (Clifford, 2001:32). According to Keane (1998:123) revolutionary feminists believe that the Judaeo-Christian tradition is so intrinsically biased in favour of the male and so fundamentally patriarchal, that it has to be rejected completely (cf. Osiek, 1997:960-961).

\subsection{Reformist Christian feminist theology}

Reformist feminist theologians have almost nothing in common with revolutionary feminist theologians. The reformist approach does not seek to revolutionise Christianity; neither do they want to replace the God as revealed in the flesh by Jesus Christ. They are looking for modest changes within existing church structures (cf. Groothuis, 1997). They share a commitment to the Christian tradition. Some followers of this form of feminist theology believe that they can solve the problems of women's secondary status with measures such as inclusive translations of the Bible and more emphasis on egalitarian 
passages in the Bible. They are of the opinion that permitting women to hold church offices and do church-related ministries will help restore the woman's place in the church (Clifford, 2001:33). This form of feminist theology has exponents that can be placed under Osiek's (1997:962) rubric of a loyalist hermeneutic and is by-andlarge the type of studies undertaken in the circles of the GKSA thus far (cf. Breed et al., 2008). Her criticism of this approach is fitting also in the GKSA context:

it ... stretch[es] history and the literal meaning of texts, and it tends to be innocent of the political implications of the types of social interaction and relationships that it advocates on the basis of fidelity to the biblical text as divine revelation (Osiek, 1997:963).

\subsection{Reconstructionist Christian feminist theology}

This group of theologians shares with reformist feminism a commitment to Christianity and they see the Bible as the means of reconstructing a positive Christian theology for women, while at the same time criticising the tradition regarding the role of woman inand outside the church (Sawyer, 1990:232). Reconstructionist feminist theologians seek a liberating theological core for women within the Christian tradition, while also working towards a deeper transformation or reconstruction not only of church structures, but also of civil society (Clifford, 2001:33).

Well-known reconstructionist Biblical scholars include Rosemary Radford Ruether, Phyllis Trible and Elisabeth Schüssler-Fiorenza. Ruether sees feminism as part of a general movement of liberation for all, both male and female, who are subjected to oppression (Sawyer, 1990:232). The aim of feminist theology according to Ruether (1983:18) is "the promotion of the full humanity of women". To her, the appeal to women's experience is of the utmost importance because it is precisely women's experience that has been shut out of hermeneutics (Thiselton, 1992:433). According to Loades (1998:82) this approach to feminist interpretation proceeds on the assumption that all, thus not just women, stand to gain from this movement. In this article particular attention will be paid to Schüssler-Fiorenza and Trible. Osiek $(1997: 963,965)$ draws a more subtle distinction here when she labels Trible as operating with a revisionist hermeneutic, whereas Schüssler-Fiorenza works from a liberationist model. We include both under the reconstructionist rubric. 


\subsection{Schüssler-Fiorenza, Trible and reconstructionist feminist Biblical interpretation}

Schüssler-Fiorenza (1983:6) argues that feminist hermeneutics is a type of liberation theology and she goes further by saying, "all theology, willingly or not, is by definition always engaged for or against the oppressed". Schüssler-Fiorenza maintains that female subordination was not part of the original gospel but rather the result of the church's eventual compromise with Graeco-Roman society (Sawyer, 1990:243).

Trible (1978:5-8) identifies the re-contextualisation of Biblical texts within the framework of a tradition as the first hermeneutical issue to be addressed. Her method is derived from rhetorical criticism as expounded by James Muilenburg (cf. Muilenburg, 1969). "How the text speaks and what it says belong together in the discovery of what it is", Trible (1978:9) writes. Her view is that male and female originates with God and therefore are equal.

A comparison will be drawn between these two theologians in the next section. Once the differences and similarities in their approaches have been described, these will be evaluated. Particular attention will then be given to how their main arguments can be applied to the question of women in the modern day church.

\section{Schüssler-Fiorenza and Trible: a comparison}

\subsection{Schüssler-Fiorenza and a historical approach to the text}

Elisabeth Schüssler-Fiorenza can certainly be viewed as one of the key contributors when it comes to the field of feminist theology. She has intensely experienced the oppression and subordination of women in the church and in society. It takes a person of courage to achieve what she has done in terms of not only feminist hermeneutics but also in terms of seeking women's rightful place in society. Although she is viewed as a German-born American by many, she sees herself as a "resident alien" (Segovia, 2003:23). Schüssler-Fiorenza is a Catholic scholar who became the first woman in Würzburg, Germany, to complete the full academic program in theology that male students for the priesthood were required to take (Clifford, 2001:62).

Schüssler-Fiorenza moved to the USA at the beginning of the 1970s, because according to her, "there was no possibility of work in Germany for me as a theologian" (Segovia, 2003:10). Clifford 
(2001:62) also mentions the important fact that Schüssler-Fiorenza became the first female president of the Society of Biblical Literature in 1987. She spent most of her academic career in North American institutions and taught at the University of Notre Dame, the Episcopal Divinity School in Cambridge, Massachusetts, and at the Harvard Divinity School (Clifford, 2001:62).

Schüssler-Fiorenza has written many works that are of great value to the field of feminist hermeneutics. She is best known for her book In memory for her: a feminist reconstruction of Christian origins (Schüssler-Fiorenza, 1983). One of the major foci in her work has been on women in the church. She consistently argues for a reformation of ecclesiology that would give proper attention to the ministry women have done and are doing in the church. She is a critical historian and has developed and applied feminist hermeneutical theory to Biblical sources. She critically appraises cultural understandings of gender and the role of patriarchy in all its facets. She has always been critical of male dominated academy that has marginalised women and their contributions to Christian history (Clifford, 2001:62).

\subsection{Trible and a literary approach to the text}

Phyllis Trible is an internationally renowned Biblical scholar and rhetorical critic. At the time of her retirement she was professor of Biblical studies at Wake Forest Divinity School. She began her teaching career as a college lecturer at Wake Forest University in 1963. In 1979 she went to Union Theological Seminary in New York as a professor in Old Testament. From 1981 until her appointment to the Wake Forest Divinity School in 1998, she was the Baldwin Professor of Sacred Literature at Union Theological Seminary. In 1994 she was elected the second female president of the Society of Biblical Literature. Besides these positions she held, Trible was a visiting professor at several other theological schools, including Vancouver School of Theology in British Columbia, and Iliff School of Theology in Denver (Wake Forest University, 2009).

Trible is considered a leader in the text-based exploration of women and gender in Scripture. In an interview with Sally Cloke (2002) during the National Anglican Conference in Sydney, where Trible was a speaker, she said the following:

Some feminists have given up on the Bible because they think it's totally patriarchal, totally andocentric. I'm not among them. But I read the Bible differently from the way it has traditionally 
been read. I ask questions that have not been asked before, and I take an interest in subjects that have not been dealt with before. For example: what difference does it make to read the Bible from the point of view of its minor characters rather than its major characters? What happens when you read the Bible in terms of the stories of the losers, rather than the winners?

This indicates Trible's commitment to reconstructionist feminists who hold the Biblical text in high regard. Trible is best known for her books God and the rhetoric of sexuality (1978), Texts of terror: literary-feminist readings of Biblical narrative (1984) in which she follows a text focused (literary) methodology. She mainly makes use of rhetorical criticism and by conducting interactive close readings of texts. She is of opinion that every reader brings to the text certain perspectives and therefore there cannot be a final interpretation of a text. Trible is committed to the Bible, but she reads it differently than it has been read traditionally and critiques unchallenged patriarchal interpretations to affirm feminist goals.

\subsection{A comparison between Schüssler-Fiorenza and Trible}

The greatest similarity between Schüssler-Fiorenza and Trible is the fact that they are both reconstructionist Christian feminist theologians who seek a liberating theological core for women within the Christian tradition, but also work towards a transformation and reconstruction of society. This calls for repentance by righting wrongs. The wrong that is of primary concern here is the effects of patriarchy on people's lives (Clifford, 2001:33-34). In order to achieve these stated goals both Schüssler-Fiorenza and Trible employ a hermeneutics of suspicion, remembrance and reconstruction in their work.

Schüssler-Fiorenza shows special interest in what lies behind the text in its historical setting. She mentions in her analysis of the book Luke that the author emphasises the execution of Jesus as the king of the Jews was a failure of the Roman justice under pressure of Jewish leadership. Luke uses this to subvert Jewish political and Roman universalist tendencies and he plays down Jewish political hopes in favour of imperial Roman theology (Schüssler-Fiorenza, 1992:212). Schüssler-Fiorenza (1992:211) further indicates that the author of Luke intends to write an historical account of Christian beginnings for an elite male audience whose domain is history. Although these statements are not given directly in the texts, Schüssler-Fiorenza is of opinion that it can be deduced from what is stated, or not, in the text. 
She also makes use of form criticism as a tool to reconstruct the social life and institutions of Biblical communities and pays particular attention to the effects of patriarchy at the time. She indicates that patriarchy originated centuries ago and was mediated through Christianity (Schüssler-Fiorenza, 1992:203). Emphasis is placed on Luke's rhetorical strategies to reveal the patriarchal structures that are inscribed in them.

Her interest in the context in which certain ideas are expressed, provides evidence of her use of tradition criticism. She also reconstructs prehistories of texts, which indicates her use of redaction criticism. Schüssler-Fiorenza (1992:210) explains in her analysis of the woman who was bent double, that the andocentric tendencies of Luke's version should not be explained away or seen as time-conditioned but these tendencies as well as the political strategies used in the text should be brought to light. This can be done through a reconstruction and recontextualisation by reading against the ideological grain (Schüssler-Fiorenza, 1992:212). The assertion that the Jewish people and leaders have rejected Jesus and caused his death is articulated in the Lucan text and should be reconstructed in the same way (Schüssler-Fiorenza, 1992:212).

Trible, on the other hand, focuses on the text itself and on the relationships of its various components to one another. Her summary of the Eve story (Trible, 1984) serves as a good example of how literary form and theological content cannot be separated. Her emphasis on the meaning of the words and terms, as well as her concern for why one term is used and not another, marks the literary orientation of her work. The fact that she emphasises the text's reference to "earth creature" rather than "man" at creation, for instance, is at the core of validating her interpretation. At several places in her analysis of the story of Jephthah's daughter she indicates the significance of the repetition of phrases. Trible (1984: 103) explains that the word that has "gone forth" from Jephthah's mouth in his vow in Judges 11:36 has become the daughter who has "gone forth" from his house in Judges 11:34. The same word is used in Hebrew and Trible links the two usages of the word.

Special attention should be paid to the fact that Trible relies on rhetorical criticism and in the story of Jephthah's daughter it is evident how she used this method to uncover rhetoric in the text. She points out that Jephthah made a human vow because of unfaithfulness. This vow can easily persuade the interpreter that Jephthah is devoted to the Lord. Then it would be justified that he keeps his vow and sacrifices his daughter. Trible's close reading, 
however, exposes Jephthah's unfaithfulness and distrust in Yahweh as well as his daughter's premature, violent and undeserved death.

It is clear that although Schüssler-Fiorenza and Trible are both classified as reconstructionist Christian feminist theologians, they differ in their approaches to the text. Their opposite stances in this regard make them good candidates when in the last section their work will be evaluated and applied in a South Africa context with a focus on the reformed tradition. Before that can be done, however, the contours of the South African context should be drawn.

\section{Women and the church in mainline reformed churches in South Africa}

\subsection{A brief history and the current role of women in the church}

The role of women in the church has been researched in South Africa for decades. According to Janse van Rensburg (2002:720) when the issue became a burning one in the latter quarter of the twentieth century both the NG Kerk (NGK: Dutch Reformed Church) and the Nederduitsch Hervormde Kerk (NHK) based their assessments of the situation on the belief that gender should not serve as the basis for any form of discrimination among church members. In research done by Van Helden (2002:762) women from both these denominations indicated that they have enough opportunities to participate in the church. In the Gereformeerde Kerke in Suid-Afrika (GKSA), however, the issue has not yet been resolved. Janse van Rensburg (2002:720) indicates that although the Bill of Rights included in the Constitution of South Africa (1996) has secured the equality of gender, women are still being discriminated against in society and, of more relevance to this study, in the church. The following subsections take a closer look at this issue.

\subsubsection{Nederduitsch Hervormde Kerk van Afrika (NHK)}

The Nederduitsch Hervormde Kerk van Afrika (NHK) must be credited for being the first of the Afrikaans protestant churches to allow a women's league as well as allowing women to serve in the offices. The following steps in the development of the role of women in the NHK should be noted:

- The traditional attitude of the NHK towards women in the special offices can be seen in a 1937 report on the right of women to vote in the church. It is explained that equality between men and 
women in the church is unacceptable (Bergh \& Barnard-Weiss, 1999:94).

- In 1940, however, the NHK became the first of the three mainline Afrikaans protestant churches to allow a women's league (Bergh \& Barnard-Weiss, 1999:91).

- Several factors, like the changing position of women in society, led to women being allowed to vote in the church in 1957 (Bergh \& Barnard-Weiss, 1999:99).

- Kleynhans (1983:19) notes that the general church meeting of the NHK allowed women as deacons in 1973. Dreyer (1999:385), a researcher from within the $\mathrm{NHK}$, indicates that this decision was taken already in 1970.

- At the following general church meeting in 1976 it was decided that research should be done on the possibility of allowing women as ministers (Kleynhans, 1983:19). Dreyer (1999:386) indicates as one of the results of this inquiry, a book by P.S. Dreyer (1977) entitled Vroue as predikante? (Women as ministers?). This book formed a point of departure for the subsequent debate on the matter.

- A report regarding women in the office of minister (VDM) was presented at the 1979 general church meeting and it was decided that women can serve in this office (Kleynhans, 1983:19).

- By 1983 female ministers attended the general church meeting (Bergh \& Barnard-Weiss, 1999:92). At this meeting a decision was taken to allow women to serve also as elders (Dreyer, 1999: 387).

- In 1995 it was decided to accommodate women in terms of inclusive language (Bergh \& Barnard-Weiss, 1999:113).

- The NHK also confirmed its willingness to publicly allow equality in 1998 when a female minister was elected as a curator.

According to Bergh and Barnard-Weiss (1999:92-97) the theoretical equality within the NHK did not necessarily resulted in the increase of women's rights within the church.

\subsubsection{Nederduitse Gereformeerde Kerk (NGK)}

According to Du Pisani (1996:250) the events in the NGK as regards finding a place for women in the special offices reflect a society that wants to be freed from the old practices in a patriarchal system that 
does not cater for the practical demands and values of a changing environment. The developments that took place in the NGK began in the 1940s. The following dates and events are of significance:

- In 1944 it is decided in the Orange Free State that female deacons can be appointed to serve where the need may occur. It is noted that it is not a fourth office but only a position for woman to serve. In 1952 the term "diakonesse-hulpdiens" (assisting deacons) is coined (Kleynhans, 1983:17).

- During the 1960s practical issues led to the reconsideration of women in the offices. A commission was appointed in 1966 to investigate the issue (Du Pisani, 1996:251).

- In 1970 it is still taken for granted that women are not allowed to become elders or ministers. The possibility of women becoming deacons is researched.

- At the synod meeting of 1974 it is emphasised that women are not allowed as elders or ministers but it is still not grounded on Scripture whether or not they can be deacons. A commission has to do further research.

- In 1978 it is decided that the Bible does not give a final answer to the question of women in the offices. The issue is referred to the regional synods to be considered. The general synod approves of women serving as assistant deacons (diakonesse-hulpdiens).

- At the general synod of 1982 it is finally decided that women are accepted in the office of deacon.

- Women as deacons are confirmed at the synod of 1986 . The decision regarding the offices of elders and ministers is postponed until the following meeting.

- In 1990 it is decided that women can serve in all the offices including elders and ministers.

In summarising this development, Du Pisani (1996:241) states: "The conclusion is reached that a definite shift away from traditional fundamentalism towards a more open and less dogmatic approach has taken place in the NGK". Even though Du Pisani also mentions the fact that in practice equality is less visible, it is of more significance to this article that women received their rightful place in the church on the basis of liberating (not liberal!) hermeneutics. This will happen wherever people accept and apply sound hermeneutical 
principles, which seek to steer clear of fundamentalism on the one and relativism on the other hand.

\subsubsection{Gereformeerde Kerke in Suid-Afrika (GKSA)}

Van Deventer (2005:690-696) gives a summary of the decisions taken by the GKSA regarding the role of women in the churches and he identifies the following events:

- At the national synod of 1918 the issue of women voting for male office bearers was tabled for the first time. Forty years later (1958) it is decided that the right of women to vote in the church implies a right to govern, and to be elected in the church offices. Hence, voting rights should not be granted for women in the church.

- In 1979 a commission was appointed by the synod to study the role and place of women in the church with regard to offices, service and voting.

- In 1982 another commission was appointed with the same assignment as the previous one, since the report presented by the 1979 commission at the synod of 1982 exhibited a lack of conclusions and recommendations.

- The process was repeated yet again at the synod of 1985. Significantly, the 1982 commission stated in their report with regard to the office of deacon that Scriptural evidence indicated the eligibility of women to be called to this office.

- An extensive report on the place of women in the church was tabled at the synod of 1988 and it was decided that since women are full members of the congregation, they might participate in the election of male office bearers.

- In the same report the conclusion was reached that in exceptional circumstances, women can be gifted and called by God to do certain services. The conclusion, however, was deemed by the synod not to be based on solid Scriptural grounds and therefore it was not accepted.

- Twice in 1994 and 1997 appeals against the 1988 decision were tabled but in both cases these were unsuccessful. Another commission was formed in 1997 to contact churches abroad regarding their positions on allowing women into the offices. 
- A further commission appointed in 2000 had to study "what the Bible reveals about the manner in which the Lord used and still uses women in his church".

- Based on this report the GKSA decided at the synod of 2003 to reverse its decision on the issue of women in the offices, when women were allowed to serve as deacons.

Van Deventer (2005:696) focuses his study on this 2003 synod decision. It should be noted, however, that a further change occurred at the synod of 2006 when an appeal carried against the 2003 decision allowing women in the office of deacon and that decision was once again reversed. This latest decision was overturned in 2009 , when the synod decided that women may serve in the office of deacon, but that the offices of elder and minister remain the sole prerogatives of men.

\subsection{Reasons for these developments}

On a theoretical level Bergh and Barnard-Weiss (1999:95) identify a patriarchal paradigm as one of the issues to be kept in mind when considering the role women play in the church. The general demise of this social paradigm after World War II and especially since the advent of the second-wave feminism in the 1960s (Weedon, 2003:111) also led to a reconsideration of the role of women in the church. Bergh and Barnard-Weiss (1999:99) indicate that the interpretation of the Bible is directly linked to the frame of reference of the interpreter. A shift in the patriarchal frame of reference also meant a shift in the way the Bible was read on the issue of women in the church. On a practical level other factors such as urbanisation, which placed a bigger work load on the church and gave women an opportunity to play a role in church activities, as well as lack of willing men to serve on church councils, played a significant role in allowing women in the special offices (Bergh \& Barnard-Weiss, 1999:101-106).

Du Pisani (1996:255) explains that at the end of the 1970s, the old generation of traditionalists in the NGK hierarchy was on their way out. A change therefore occurred in the NGK's official view on the position of women in the church. Van Deventer (1990:5) indicates that this change was grounded on a new interpretation of Biblical texts, which was previously used to justify male superiority. This new interpretation was related to the historical-critical method that opened the eyes to the vast historical differences between an ancient text related to the Greco-Roman world and a present-day con- 
text. In the South African context the results of historical criticism were incorporated in the theological debate especially in the context of the NHK, albeit according to Breytenbach (1999:176) through the mediation of dialectical theology. The use of this method and its results by a NHK theologian can be seen in a study related to the issue of women in the ministry dating already from the mid-1970s (cf. Pelser, 1976). This study received the accolade "excellent" from a NGK theologian after the turn of the century (Du Toit, 2001:172). Studies related to the issue of women in the ministry in the GKSA do not refer to this article by Pelser, probably because a historical critical approach is not appreciated in that context.

Van Deventer (2005:696) points out that the core problem in the GKSA is a hermeneutical one. The lack of reflection by the GKSA on hermeneutical developments in the twentieth century resulted in a too narrow approach to the text. This naïve-realistic approach that is followed in the GKSA limits the interpretation of the text by among others ignoring the role of the reader. This implies that regardless of the circumstances, the GKSA has interpreted certain texts in the "correct" way, leaving no room for new ideas and approaches - such as, among others, historical criticism. The possibility that this "correct way" of reading is flaunted by the influence of the reader's presuppositions is not considered. Might this be the reason why objecttions against the synod's decision were in some cases just viewed as "not founded on good exegesis" (Van Deventer, 2005:692)? Should this be true more questions will arise like "What is good exegesis?" or "Which approach is correct?" These questions are very relevant to this study and beg the following: Can the approaches to the text of Schüssler-Fiorenza or Trible be viewed as "good exegesis"?

\subsection{Hermeneutical evaluation}

In theory the NHK and NGK have overcome the problem regarding the role of women in the church. This study focuses primarily on the GKSA because of the need to still give a theoretical solution to the problem of the role of women in the church.

One of the main reasons for the lack of a theoretical solution to the problem concerning the role of women in the GKSA is because central developments in hermeneutics have not been investigated thoroughly. This results in limitations with regard to the newer insights in terms of historical and literary aspects of texts, as well as the role played by the reader in interpretation. The traditional approach to exegesis within the GKSA is labelled as grammatical- 
historical (Krüger, 2006:28). An illustration thereof can be seen in the explanation of Coetzee et al. (1980:26) of what Paul meant in 1 Corinthians 14:34 when he commands women to be quiet during services. In terms of the historical part of this approach the GKSA in essence does not take into consideration the important distinction between the "history in the text" and the "history of the text" (Hayes \& Holladay, 1987:45). The first expression refers to what the text narrates about events while the second is concerned with the history of the text itself.

With regard to the grammatical aspect of the grammatical-historical approach, the GKSA sees it as referring to linguistics. Krüger (2006:28) points out that the term grammatical encompasses the confession that the Bible was inspired by God but it also implies that every word carries meaning. Kaiser (1994:33), however, indicates that when Keil originally used this term in 1788, it referred to the term literal, meaning "simple, plain, direct or ordinary" and not necessarily linguistics. In concluding this hermeneutical evaluation it should be said that the existing interpretation model has not seriously considered the developments in hermeneutics and specifically Biblical hermeneutics over the past half a century. Recent contributions from theologians still working in the old paradigm failed to make any impact regarding decisions about women in the offices of elder and deacon (cf. Breed et al., 2008; Helberg, 2008). It just goes to show how interpreters are in the final analysis also influenced by their subjective perspectives on "what the text says" - another aspect that hermeneutical theory has underlined especially over the past three decades (cf. Osiek, 1997:963; Van Deventer, 2005).

\section{A consideration of Schüssler-Fiorenza and Trible's approaches to the issue of women in the church}

It was evident from a previous section that both Schüssler-Fiorenza and Trible emphasise the role of the Biblical text in their hermeneutical approach but each introduces new insights in dealing with the text. These insights are rooted in the development of hermeneutics. The reason for their approaches to the text is the fact that they questioned the kind of interpretation that led to the subordination of women in Christian communities. Their "hermeneutics of suspicion" referred to above (4.3) is suspicious of the unstated power-relations informing oppressive interpretations. In the reformed tradition this kind of questioning should always be present since this tradition took root in the questioning of the authoritative interpretation of the church. Modern men and women in the GKSA should once again 
evaluate their faithfulness to Scripture in terms of the role of women in the church. According to Van Helden (2002:768) many women in the GKSA feel that they have been deceived for decades. They are of opinion that un-Biblical interpretations, translations and traditional views and practices have kept them from the truth.

\subsection{The historical approach and reformed theology in South Africa}

According to Le Roux (1994:198) the future of historical criticism in South Africa is linked to its past. South Africa has missed the challenge of dealing with the results of the Aufklärung that introduced the historical-critical method in Europe. This made European theologians realise the humanness of the Old Testament. South Afri$\mathrm{ca}$, instead, took another direction because we never experienced the pressure of working with the historical-critical method and its results, except to some extent in the NHK tradition as noted above. Le Roux (1994:199) elaborates that our theological past did not accommodate the historical-critical method and its results and therefore neither the historical-critical method nor a critical theology has taken root in South Africa.

Spangenberg (1994:156) summarises the historical-critical paradigm as follows: the Bible is a collection of old Near-Eastern religious writings, which were written by limited people who in their humanness can err. Several of these writings developed over a long period of time and they were often written by more than one author. These writings include the religious insights and religious testimonies of those people and their contemporaries. These people lived during a specific time in history at specific places on earth. To understand the Bible correctly, the reader must posses the necessary knowledge in terms of the history of Israel and other old Near-Eastern nations as well as early Christianity, the cultural setting of those people, their worldview and their religious beliefs and practices.

Le Roux (1994:200) identifies two reasons why historical criticism was neglected. Firstly, it was the belief of many followers of the structural (text immanent) approach that theirs was the only valid approach to the Bible. Secondly, there was the estrangement of history and exegesis that included the modernist belief that "history" referred to "historical facts" investigated only to see if something really happened. This view of history has caused alienation between history and theology and between history and exegesis (Le Roux, 1993:23-42). 
Van Helden (2002:756) indeed mentions that the Bible must never be separated from the cultural-historical information that forms part of it. Vergeer (2002:668) points out, however, that some people are upset by the change in meaning that is brought about by using information outside the text. In order to change the current situation in terms of the historical-critical approach to the Bible, a historical consciousness must be cultivated and the method rediscovered as a means of giving meaning to life (Le Roux, 1994:202).

Interpreters should take into consideration as many as possible socio-historical perspectives to understand the meaning of a specific part of Scripture in its original context (Vergeer, 2002:670). The historical approach to a text will help to discover which guidelines are timeless and which ones are time-bound. Schüssler-Fiorenza's use of the historical approach will now be analysed to see to what extend it can make a positive contribution to the debate.

\subsection{Schüssler-Fiorenza's approach}

Schüssler-Fiorenza's awareness of the way in which the context of both the text and the reader determines the meaning of a text is of great value. It was seen that Schüssler-Fiorenza is of the opinion that a text has a specific message within a specific community. The reader is not always aware of the liberating message that texts offer and therefore the prejudice of the reader should be dismantled for this message to surface. If the GKSA can apply this insight by a model going beyond tradition and patriarchy and in so doing encounter the liberating message of some texts, it can lead to the liberation of women in the church. In order to apply her insights to the current issue, her hermeneutical objectives as identified by $\mathrm{Ng}$ (2002:13) will serve as foundation.

- Schüssler-Fiorenza (1975:605-626) makes use of the critical theory of the Frankfurt School that criticises what is experienced as alienation and oppression. Women are alienated from taking their rightful place in the GKSA, thus also serving as leaders. This alienation, in essence, is a form of oppression. Schüssler-Fiorenza's approach can therefore be applied to criticise the alienation that is experienced in the GKSA.

- Schüssler-Fiorenza (1983:6) employs some ideas of liberation theologies, which gave the insight that theology is engaged for or against the oppressed. According to Van Helden (2002:770) the women in the GKSA have an intense, suppressed and mostly unspoken desire to be equipped and acknowledged as doers of 
the Word. If a liberation hermeneutics is applied this limitation can be rectified. The GKSA women themselves recommend that opportunities for participation in the body of Christ by women must be expanded so that liberation in Christ can be experienced in its fullest sense (Van Helden, 2002:770). It is clear that women in the GKSA cannot be reckoned as following revolutionary feminist theology, hence the years of tolerance. The GKSA woman must, however, take her position in Christ and call on the liberating Word of God to correct the theology that limited her as the oppressed in the past (Van Helden, 2002:768).

- Schüssler-Fiorenza (1992:46) often uses the term rhetorical criticism to denote the approach of a communication that links knowledge with action. Wuellner (1987:448) states in similar vein:

Rhetorical criticism of literature takes the exegetes of biblical literature beyond the study of theological or ethical meanings of the text to something more inclusive then semantics and hermeneutics.

Wuellner (1987:449) further explains that rhetorical criticism goes beyond language as a reflection of reality but rather focuses on language as a possible instrument of influence. This form of rhetorical criticism is one that emphasises the persuasive power of a text. In the context of the GKSA it has to be noted that the persuasive power of a text may and can work against traditional ideological stances such as patriarchy. In fact, a reformed model of understanding demands that it does exactly this.

- Schüssler-Fiorenza (1984:8) finds liberation theologies alone not critical enough of patriarchy as a system oppressive to woman. Thus she insists on putting the liberation of women at the centre of her thinking. This implies that a text is approached from the viewpoint and experience of women. This approach is needed since the Bible at large is more "male-centred". Janse van Rensburg (2002:721) lists some problems in this regard related to hermeneutics and the reading of sacred texts. A women-centred interpretation cannot be done by men alone, since it primarily involves women's experience. In the context of the GKSA this voice can only be heard if the doors at the synod meetings are opened for women as well.

Finally, the importance of developing a historical consciousness should be stressed. A historical understanding of reality and the text is more important than a specific method. However, it is in the 
search for truth behind the text that the historical-critical method can play an indispensable role (Le Roux, 1994:201-202).

\subsection{The literary approach and reformed theology in South Africa}

As early as 1933, Du Plessis (1933:523) posed the question whether or not the view of the GKSA on the role of women was in accordance with Scripture or whether it was only an old human tradition. When Scripture is approached in the text-centred way Trible suggests an answer to this question is possible. It seems, however, that such an approach is not utilised by theologians of a Reformed persuasion as yet.

This "new" approach among South African Biblical scholars developed almost four decades ago. The development led to a new understanding of the Bible and terms like "structural analysis" and "immanent exegesis" were coined to describe it. It had far-reaching consequences for the understanding of the Old Testament, but at the same time also led to an undervaluation of historical criticism (Le Roux, 1994:200).

In 1971 Vorster proposed this new approach in a paper read at the annual meeting of the New Testament Society of South Africa (cf. Le Roux, 1993:28). In this proposed literary approach the focus fell on the final form of a text and led to the dismissal of information about the text's historical growth. The terminology introduced included the following: diachrony (referring to the historical approach), synchrony, and structural analysis. As Le Roux (1993:28) puts it: "Something really new was introduced, which set New Testament scholars in motion and resulted in a new approach that subsequently received the status of a 'n ormal science'".

\subsection{Trible's approach}

Pieterse (2002:712) notes that another question in the debate on the role of women in the GKSA is whether men and women are equal before God. The answer to this question largely determines people's interpretation of relevant Scriptures regarding women in the offices. Trible's (1978:72-143) interpretation of Genesis 2-3, the "Eve-story", convincingly answers this question.

- Trible shows how she grounds in Scripture the notion that men are not superior to women as was believed for centuries under influence of a patriarchal ideology. This belief resulted in the 
GKSA's interpretation of Scripture in a male-orientated way and their view of women in the church.

In the very act of distinguishing female from male, the earth creature describes her as 'bone of my bones and flesh of my flesh' (Gen. 2:23). These words speak unity, solidarity, mutuality and equality. Accordingly, in this poem the man does not depict himself as either prior or superior to the woman. His sexual identity depends upon her even as hers depends upon him. For both of them sexuality originates in the one flesh of humanity. (Trible, 1978:98-99.)

- When Trible refers to the concepts of "unity, solidarity, mutuality and equality" they refer to man and women as a whole. The implication is therefore that they are equal in all aspects of life, including church life. This further implies that women and men can fulfil any function in the church, be it deacon, elder, minister or Sunday school teacher.

- According to Trible (1978:101) nowhere in the narrative has subordination a connotation to the phrase "taken from" that is used in Genesis 2:21. For both the man and the woman, life originates with God. This confirms what was said previously: men and women are in essence equal before God.

- Trible (1978:97) furthermore explains that it cannot be derived from Genesis 2-3 that men is superior to women or have power over them since no purpose is stated in God's bringing of the women to the earth creature. Previously God brings animals to the earth creature to name them and plants to take care of them, but God specifically does not give the earth creature authority over the woman and she thus does not fit the pattern of dominion as was seen in the previous episodes with the animals and the plants.

If this interpretation that men have no God-given authority over women and are not superior to them is applied in a church context, then commissions will not be needed to research endlessly the role of women in the church with no result. The text immanent approach can also be applied to interpret the "problem texts" like 1 Corinthians 14 and 1 Timothy 2 to liberate women from the belief that they are subordinated by divine command.

\section{Conclusion}

In this article newer developments within the field of Biblical interpretation were noted. After discussing what one such development, 
namely feminist criticism, entails, the attitude of reformational theology as expounded in the GKSA towards both the historical and literary approaches to the Bible was discussed. Some of the Afrikaans churches within a reformed tradition seem to stand critical to historical approaches (as used by Schüssler-Fiorenza). It may further be concluded that there seems to be a limited knowledge related to the application of developments in interpretation from a text-centred approach (as used by Trible). This implies that such churches are, because of ignorance regarding and/or rejection of new methods, stuck in old approaches to the text. Such a rigid approach within the dynamic science of Bible interpretation resulted in women not being allowed to fulfil their calling, but instead play a submissive role in the church.

\section{List of references}

BERGH, J. \& BARNARD-WEISS, M. 1999. Stappe op die pad van gelykmatiging vir die vrou in die Nederduitsch Hervormde Kerk van Afrika. Studia historiae ecclesiasticae, 25(2):91-120.

BREED, D.G., JANSE VAN RENSBURG, F. \& JORDAAN, G.J.C. 2008. Manlik en vroulik in die kerk: geslagtelikheid en die besondere dienste. Potchefstroom: Potchefstroomse Teologiese Publikasies.

BREYTENBACH, A.P.B. 1999. Ontwikkelings en verskuiwings in ons teologie. (In Van Wyk, D.J.C., red. 20ste eeu hervormde teologie. Pretoria: Sentik. p. 171-182.)

CARMODY, D.L. 1995. Christian feminist theology. Oxford: Blackwell.

CLIFFORD, A.M. 2001. Introducing feminist theology. New York: Orbis.

CLOKE, S. 2002. Phyllis Trible: life and death choices in reading the Bible. http://www.media.anglican.com.au/tma/2002/2002-09/trible.htlm Date of access: 31 Aug. 2002.

COETZEE, J.C., DE KLERK, B.J. \& FLOOR, L. 1980. Die hermeneuse van die Skrif met die oog op hedendaage kerklik-etiese vraagstukke. Koers, 45(1):18-36.

DALY, M. 1983. Voorbij God de Vader: op weg naar een feministische bevrijdingsfilosofie. Vert. E. Pars. Amersfoort: Horstink.

DREYER, P.S. 1977. Vroue as predikante? Pretoria: HAUM.

DREYER, Y. 1999. Vroue in die ampte. (In Van Wyk, D.J.C., ed. 20ste eeu hervormde teologie. Pretoria: Sentik. p. 385-390.)

DU PISANI, J.A. 1996. Die vrou se posisie in kerk en samelewing: evolusie van die Nederduitse Gereformeerde Kerk se standpunt. Koers, 61(3):241- 269.

DU PLESSIS, J.A. 1933. Die Gereformeerde vrou. Deel 2. Die Kerkblad, p. 522524.

DU TOIT, A. 2001. Die swyggebod van 1 Korintiërs 14:34-35 weer eens onder die loep. Hervormde teologiese studies, 57(1 \& 2):172-186.

GILLINGHAM, S.E. 1998. One Bible, many voices. Grand Rapids: Eerdmans.

GROOTHUIS, R.M. 1997. Good news for women: a Biblical picture of gender equality. Grand Rapids: Baker.

HAYES, J.H. \& HOLLADAY, C.R. 1987. Biblical exegesis: a beginner's handbook. London: SCM. 
HELBERG, J.L. 2008. Die buitengewone geboorte van Jesus Christus en die regering van sy kerk, in besonder rakende die vrou. In die Skriflig, 42(3):409-429.

JANSE VAN RENSBURG, F. 2002. Women in church and society: report of research done by a research team at the $\mathrm{PU}$ vir $\mathrm{CHO}$. In die Skriflig, 36(4):717-752.

KAISER, W.C. 1994. The meaning of meaning. (In Kaiser, W.C. \& Silva, M. An introduction to Biblical hermeneutics. Grand Rapids: Zondervan. p. 27-45.)

KEANE, M. 1998. Feminist and womanist theology. (In Maimela, S. \& König, A., eds. Initiation into theology: the rich variety of theology and hermeneutics. Pretoria: Van Schaik. p. 121-135.)

KLEYNHANS, E.P.J. 1983. Die vrou en die amp in die Nederduitse Gereformeerde Kerk. Bloemfontein: Universiteit van die Oranje Vrystaat.

KRÜGER, A.J. 2006. Skrifkritiek, fundamentalisme en grammaties-historiese eksegese. Die Kerkblad, p. 28-29.

LE ROUX, J.H. 1993. A story of two ways: thirty years of Old Testament scholarship in South Africa. Pretoria: Verba Vitae.

LE ROUX, J.H. 1994. Historical criticism - the end of the road? Old Testament essays, 7(4):198-202.

LOADES, A. 1998. Feminist interpretation. (In Barton, J., ed. Cambridge companion to Biblical interpretation. Cambridge: Cambridge University Press. p. 81-94.)

MUILENBURG, J. 1969. Form criticism and beyond. Journal of Biblical literature, 88(1):1-18.

NEWPORT, J.P. 1996. Contemporary philosophical, literary and sociological hermeneutics. (In Corley, B., Lemke, S. \& Lovejoy, G., eds. Biblical hermeneutics: a comprehensive introduction to interpreting Scripture. Nashville: B \& H. p. 133-144.)

NG, E.Y.L. 2002. Reconstructing Christian origins? The feminist theology of Elisabeth Schüssler-Fiorenza: an evaluation. Carlisle: Paternoster.

OSIEK, C. 1997. The feminist and the Bible: hermeneutical alternatives. Hervormde teologiese studies, 53(4):956-968.

PELSER, G.M.M. 1976. Women and the ecclesiastical ministries in Paul. Neotestamentica, 10:92-109.

PHILLIPS, V.C. 1999. Feminist interpretation. (In Hayes, J.H., ed. Dictionary of Biblical interpretation: A-J. Nashville: Abingdon. p. 388-398.)

PIETERSE, R. 2002. Die "vroue-kwessie" in die GKSA. In die Skriflig, 36(4):691-716.

RUETHER, R.R. 1983. Sexism and God-talk: toward a feminist theology. Boston: Beacon.

SAWYER, D.F. 1990. Feminist interpretation. (In Coggins, R.J. \& Houlden, J.L., eds. A dictionary of Biblical interpretation. London: SCM. p. 231-234.)

SCHÜSSLER-FIORENZA, E. 1975. Feminist theology as critical theology of liberation. Theological studies, 36:605-626.

SCHÜSSLER-FIORENZA, E. 1983. In memory of her: a feminist theological reconstruction of Christian origins. New York: Crossroad.

SCHÜSSLER-FIORENZA, E. 1984. Bread not stone: the challenge of feminist Biblical interpretation. Boston: Beacon.

SCHÜSSLER-FIORENZA, E. 1985. Remembering the past and creating the future. (In Collins, A.Y., ed. Feminist perspectives on Biblical scholarship. p. 43-64.) 
SCHÜSSLER-FIORENZA, E. 1992. But she said: feminist practices of Biblical interpretation. Boston: Beacon.

SCHÜSSLER-FIORENZA, E. 2001. Wisdom ways. New York: Orbis.

SEGOVIA, F.F. 2003. Looking back, looking around, looking ahead. (In Segovia, F.F., ed. Toward a new heaven and a new earth. New York: Orbis. p. 1-30.)

SPANGENBERG, I.J.J. 1994. Paradigmaveranderinge in die Bybelwetenskappe: 'n bydrae tot die gesprek tussen die Bybelwetenskappe en sistematiese teologie. Religie \& teologie 1(2):144-184.

THISELTON, A.C. 1992. New horizons in hermeneutics: the theory and practice of transforming Biblical reading. Grand Rapids: Zondervan.

TRIBLE, P. 1978. God and the rhetoric of sexuality. London: SCM.

TRIBLE, P. 1984. Texts of terror. Philadelphia: Fortress.

VAN DEVENTER, H.J.M. 2005. Why minds are changed: an inquiry into the decisions by the Gereformeerde Kerke in Suid Afrika (GKSA) on the role of women in the church. Koers, 70(4):685-704.

VAN DEVENTER, L. 1990. Die vrou as leraar, ouderling ... wat sê die Bybel regtig? Die Kerkbode, 145(2):5.

VAN HELDEN, P. 2002. Die aktiwiteit van die belydende GKSA-vrouelidmaat tydens die erediens. In die Skriflig, 36(4):755-783.

VERGEER, W.C. 2002. Anomalieë in die Gereformeerde standpunt oor die rol van die vrou in die kerk. In die Skriflig, 36(4):661-689.

WAKE FOREST UNIVERSITY. 2009. Phyllis Trible: the divinity school at Wake Forest University. http://divinity.wfu.edu/faculty-trible.html Date of access: 1 March 2009.

WEEDON, C. 2003. Subjects. (In Eagleton, M., ed. A concise companion to feminist theory. Oxford: Blackwell. p. 111-132.)

WUELLNER, W. 1987. Where is rhetorical criticism taking us? Catholic Biblical quarterly, 49:448-463.

\section{Key concepts:}

feminism

Reformed Churches in South Africa

Schüssler-Fiorenza, E.S.

Trible, $\mathrm{P}$.

women in church

Kernbegrippe:

feminisme

Gereformeerde Kerke in Suid-Afrika

Schüssler-Fiorenza, E.S.

Trible, $P$.

vroue in die kerk 